\title{
Front Matter: Volume 11718
}

, "Front Matter: Volume 11718," Proc. SPIE 11718, Advanced Topics in Optoelectronics, Microelectronics and Nanotechnologies X, 1171801 (31 December 2020); doi: 10.1117/12.2592062

SDIE Event: Advanced Topics in Optoelectronics, Microelectronics and SPIE. Nanotechnologies 2020, 2020, Online Only 


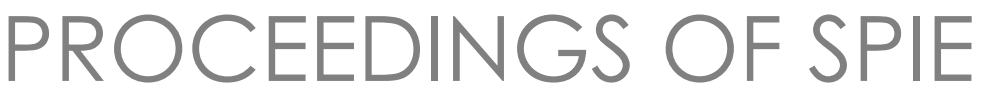

\title{
Advanced Topics in Optoelectronics, Microelectronics and Nanotechnologies $X$
}

\author{
Marian Vladescu \\ Razvan Tamas \\ Ionica Cristea \\ Editors
}

20-23 August 2020

Constanta, Romania

Sponsored by

Ministry of Research and Innovation (Romania)

University Politehnica of Bucharest (Romania)

Maritime University of Constanta (Romania)

Organized by

University Politehnica of Bucharest, Optoelectronics Research Center (Romania)

Maritime University of Constanta (Romania)

Cooperating Organisation and Publisher

SPIE

Volume 11718 
The papers in this volume were part of the technical conference cited on the cover and title page. Papers were selected and subject to review by the editors and conference program committee. Some conference presentations may not be available for publication. Additional papers and presentation recordings may be available online in the SPIE Digital Library at SPIEDigitalLibrary.org.

The papers reflect the work and thoughts of the authors and are published herein as submitted. The publisher is not responsible for the validity of the information or for any outcomes resulting from reliance thereon.

Please use the following format to cite material from these proceedings:

Author(s), "Title of Paper," in Advanced Topics in Optoelectronics, Microelectronics and Nanotechnologies X, edited by Marian Vladescu, Razvan Tamas, Ionica Cristea, Proceedings of SPIE Vol. 11718 (SPIE, Bellingham, WA, 2020) Seven-digit Article CID Number.

ISSN: 0277-786X

ISSN: 1996-756X (electronic)

ISBN: 9781510642713

ISBN: 9781510642720 (electronic)

Published by

SPIE

P.O. Box 10, Bellingham, Washington 98227-0010 USA

Telephone +1 3606763290 (Pacific Time) · Fax +1 3606471445

SPIE.org

Copyright (c) 2020, Society of Photo-Optical Instrumentation Engineers.

Copying of material in this book for internal or personal use, or for the internal or personal use of specific clients, beyond the fair use provisions granted by the U.S. Copyright Law is authorized by SPIE subject to payment of copying fees. The Transactional Reporting Service base fee for this volume is $\$ 21.00$ per article (or portion thereof), which should be paid directly to the Copyright Clearance Center (CCC), 222 Rosewood Drive, Danvers, MA 01923. Payment may also be made electronically through CCC Online at copyright.com. Other copying for republication, resale, advertising or promotion, or any form of systematic or multiple reproduction of any material in this book is prohibited except with permission in writing from the publisher. The CCC fee code is $0277-$ $786 \mathrm{X} / 20 / \$ 21.00$.

Printed in the United States of America by Curran Associates, Inc., under license from SPIE.

Publication of record for individual papers is online in the SPIE Digital Library.

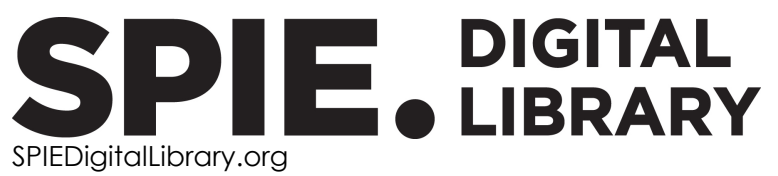

Paper Numbering: Proceedings of SPIE follow an e-First publication model. A unique citation identifier (CID) number is assigned to each article at the time of publication. Utilization of CIDs allows articles to be fully citable as soon as they are published online, and connects the same identifier to all online and print versions of the publication. SPIE uses a seven-digit CID article numbering system structured as follows:

- The first five digits correspond to the SPIE volume number.

- The last two digits indicate publication order within the volume using a Base 36 numbering system employing both numerals and letters. These two-number sets start with $00,01,02,03,04$, 05, 06, 07, 08, 09, OA, OB ... 0Z, followed by 10-1Z, 20-2Z, etc. The CID Number appears on each page of the manuscript. 


\section{Contents}

\section{ADVANCED TOPICS IN OPTOELECTRONICS, MICROELECTRONICS AND NANOTECHNOLOGIES X}

1171802 On the dynamics of shaping: the generalization of the morphogenesis [11718-2]

$1171803 \quad$ Fractals: the missing link between certainty and uncertainty [11718-3]

1171804 Carbon nanoparticles: preparation and specially formed optical properties [11718-4]

1171805 Carbon nanoparticles for diagnostic of random speckle-fields: Hilbert transformation application [11718-5]

1171806 The benefit of nanoparticles add to R600a in a vapor compression system [11718-6]

1171807 Improvement of gas turbines performance through erosion resistant nanocoatings and exergy analysis [11718-7]

1171808 Evanescent waves: extraordinary manifestation in biomedical application (Invited Paper) [11718-8]

$1171809 \quad 3 D$ LED cube [11718-9]

$117180 \mathrm{~A} \quad$ System for monitoring the parameters of vehicle [11718-10]

$11718 \mathrm{OB} \quad$ Methods of underwater autonomous navigation [11718-11]

11718 OC Electromagnetic radiation monitoring universal device [11718-12]

$117180 \mathrm{OD}$ Software-defined ground penetrating chirp radar [11718-13]

11718 OE Continuous-wave software-defined radar interferometry [11718-14]

11718 OF Stepped-frequency software-defined ground-based synthetic aperture radar [11718-15]

$117180 G$ Stepped-frequency software-defined ground penetrating radar [11718-16]

$11718 \mathrm{OH} \quad$ Numerical modeling of mixed-mode delamination fracture in unidirectional AS4/PEEK composites [11718-17]

$117180 \mathrm{Ol} \quad$ Numerical analysis of fluid flow and mixing performance for a SAR-based passive micromixer [11718-18] 
$117180 \mathrm{~J} \quad$ Investigations of non-grain oriented Si steel sheets [11718-19]

11718 OK Efficiency of using a hybrid marine propulsion system vs. conventional system [11718-20]

$11718 \mathrm{OL} \quad$ Big data integration: an evolutionary perspective [11718-21]

$117180 \mathrm{M} \quad$ Choose the best electricity sources for a container ship by using a hybrid optimization model for electric renewable [11718-22]

$117180 \mathrm{~N} \quad$ Bio-algorithms for decision making [11718-23]

$1171800 \quad$ Polarization-phase mapping of the optically anisotropic component of biological tissues in the differential diagnosis of sepsis [11718-25]

11718 OP Statistical analysis of vector-parametric polarization images of the polycrystalline component of biological tissues with varying degrees of necrotic changes [11718-26]

$117180 Q \quad$ Optical selection rules for the quantum transitions from the ground state of the crystal to the superposition states of the two-dimensional magneto-excitons [11718-27]

11718 OR Biofouling monitoring [11718-29]

11718 OS Quantum random number generation with down converted photon pairs [11718-31]

11718 OT Performance targets and QoS requirements for the service provided to users/subscribers of public IP networks [11718-32]

$117180 \mathrm{U} \quad$ Heat transfer modeling in the hot source area of flat micro heat pipe [11718-34]

$117180 \mathrm{~V}$ Experimental research on cooling the condensation area to flat micro heat pipe using the inverted Seebeck effect [11718-35]

$11718 \mathrm{OW} \quad$ Realistic models of cultured cells for electroporation simulations starting from phase images [11718-37]

$117180 \mathrm{X} \quad$ Photoconductivity spectra of amorphous multilayer structures [11718-38]

11718 OY Conservation of wooden artifacts: evaluation of modern and classical materials [11718-40]

$117180 Z$ Some trends in optical metrology [11718-41]

1171810 Experimental evaluation of the air flow rate and boost pressure by aid of the diaphragm method for an electrically driven axial compressor [11718-44]

1171811 Compression ratio influence on the performances of a diesel engine equipped with an electrically driven axial compressor [11718-45]

1171812 Distribution of droplets in an atomized combustible jet depending on the surface of the atomized jet of fuel [11718-46] 
1171813 The modification of vaporization times and the evolution analyze of diameters of fuel drops depending about gaseous ambient temperature [11718-47]

1171814 VOF method developed for the evaporation of liquid droplets that come into contact with heated surfaces [11718-51]

1171815 Simulation of the impact of a liquid jet upon contact with a perpendicular surface versus an inclined one [11718-52]

$1171816 \quad$ Numerical modeling of centrifugal microfluidic flow in rectangular channels for Lab-on-a-CD platform applications [11718-53]

1171817 Managing the luminescence efficiency of the organic compounds of europium(III) through preparation technology [11718-54]

1171818 Photosensivity of heterostructures produced by aerosol deposition of ZnMgO thin films on Si substrates [11718-55]

$1171819 \quad$ Numerical simulation of air lift pump system using volume of fluid method [11718-56]

$117181 \mathrm{~A}$ The use of homodyne detection for measuring small frequency differences between two RF oscillators [11718-58]

11718 1B Differential Mueller-matrix tomography of the polycrystalline structure of histological sections in the histological determination of the limitation of the damage formation of human internal organs [11718-59]

$117181 \mathrm{C}$ Polarization reconstruction of fluctuations in the parameters of the phase anisotropy of biological crystals networks in differentiation of cerebral infarction [11718-60]

11718 1D Phase reconstruction of the polycrystalline structure of internal organs tissues in the differentiation of alcohol and carbon monoxide poisoning [11718-61]

$11718 \mathrm{IE} \quad$ Mueller-matrix differentiation of necrotic changes in polycrystalline structure of partially depolarizing layers of biological tissues [11718-62]

$117181 \mathrm{~F} \quad$ Differential mapping of depolarization component of Mueller matrix of optically thick biological layers [11718-63]

$117181 \mathrm{G}$ Control surface roughness of mirror [11718-64]

$117181 \mathrm{H}$ Spectropolarimetry differential diagnosis of adenocarcinoma and squamous cell cervix carcinoma [11718-65]

1171811 Diagnosis of cervical cytological smears for availability of papillomavirus by spectropolarimetry [11718-66]

$117181 \mathrm{~J} \quad$ Azimuthally invariant Mueller-matrix tomography of linear dichroism of polycrystalline networks of biological tissues [11718-67] 
$117181 \mathrm{~K} \quad$ Molecular spectrometry of the blood of breast cancer patients as a preliminary stage of further molecular genetic screening [11718-68]

$117181 \mathrm{~L} \quad$ Study performed on two lavender oils from different Romanian areas [11718-69]

$117181 \mathrm{M} \quad$ Processing of spectral imaging of deep layers in the macula of the retina in diabetic macular edema [11718-70]

$117181 \mathrm{~N}$ Optical investigations of the 3D printing regime influence on surface parameters [11718-71]

1171810 Command and control of platforms for scanning soil properties [11718-72]

$117181 \mathrm{P} \quad$ Experimental investigations regarding contact mean pressure in four balls test [11718-74]

$117181 Q \quad$ Analysis of passive vs. semi-active quarter car suspension models [11718-76]

$117181 \mathrm{R} \quad$ Tunnel junctions in Bi and Bi0.97Sbo.03 nanoconstrictions [1 1718-77]

11718 is Employment of $Y_{\mathrm{r}_{\mathrm{r}}} \mathrm{C}_{\mathrm{b}}$ color space and OLED display for enhancement of hyperspectral images colors rendering [1 11718-78]

$117181 \mathrm{~T} \quad$ Experimental stand of absorption measurements in the $8.6-9.5 \mathrm{GHz}$ range for very thin samples with offset of the reflected wave phase [11718-80]

$117181 \mathrm{U} \quad$ Mechatronic platform with sensors for smart agriculture [1 1718-81]

$117181 \mathrm{~V} \quad$ Seismic qualification by analysis of an overhead crane for nuclear industry [11718-82]

$117181 \mathrm{~W}$ Optimization study of a centrifugal pump in cavitation [1 1718-83]

$117181 \mathrm{X} \quad$ Algorithm for frequency dependent properties of dielectric materials in high speed interconnections [1 1718-84]

$117181 \mathrm{Y} \quad$ Enhancement of the optical polarization effect on the SPR response in gold micro/nanoparticles imaging (Invited Paper) [11718-85]

$1171812 \quad$ Temperature dependence of I-V characteristics of dye sensitized solar cells [11718-86]

$1171820 \quad$ Vulnerabilities in authentication process GSM standard: RF measurements, theoretical and practical aspects [11718-87]

$1171821 \quad$ Processing gain considerations on compromising emissions [11718-88]

$1171822 \quad$ Cyber-physical healthcare security system based on a Raspberry Pi [11718-89]

1171823 Analysis of PS/2 compromising emanations [11718-90] 
$1171824 \quad$ OFDM in downlink MASSIVE-MIMO system [11718-91]

1171825 Measurements of the emission parameters of a WiMax BTS under interference conditions [11718-92]

1171826 Effect of reducing the background noise in the detection of blood lead [11718-94]

1171827 An optoelectronic biomedical method for amphetamine detection by enzyme multiplied immunoassay technique [11718-95]

$1171828 \quad$ Modeling of nuclear radiation detection with MEMS [11718-96]

1171829 Contributions to the analysis of substances with time-domain terahertz spectroscopy [11718-97]

$117182 \mathrm{~A} \quad$ Radar cross section analysis for meander line frequency selective surfaces [11718-98]

11718 2B Security and propagation issues and challenges in VLC and OCC systems [11718-100]

$117182 \mathrm{C} \quad$ Low cost seismometer for building integrity measurement [11718-101]

$117182 \mathrm{D}$ On the improvement of performance in motorsport by means of acceleration measurements [11718-102]

$117182 \mathrm{E} \quad$ An overview on optoelectronic methods for detection of xenobiotics in human fluid samples [11718-103]

$117182 \mathrm{~F} \quad$ Visible light communications: current challenges and prospects [11718-104]

$117182 \mathrm{G}$ Characterization of antenna side and back radiation in a multipath site [11718-105]

$117182 \mathrm{H} \quad$ The performance of Manchester source coding in an uplink LDPC channel coding OFDMbased massive MIMO system [1 1718-108]

$1171821 \quad$ Time and power performance study on 8-bit microcontrollers [11718-110]

$117182 \mathrm{~J} \quad$ Key extraction in a chaos-based image cipher and wavelet packets [11718-111]

$117182 \mathrm{~K} \quad$ Photophysics of poly(3,4-ethylenedioxythiophene) covered by permodified Y-cyclodextrin [11718-112]

$117182 \mathrm{~L} \quad$ Operation and diagnosis of electrically operated valves [11718-113]

$117182 \mathrm{M}$ Operation and diagnosis of pneumatically operated valves [11718-114]

$117182 \mathrm{~N} \quad$ Parallel machine simulator using racket/scheme functional programming language [11718-115] 
1171820

$117182 \mathrm{P}$

$117182 \mathrm{Q}$

$117182 R$

$117182 S$

$117182 \mathrm{~T}$

$117182 \mathrm{U}$

$117182 \mathrm{~V}$

$117182 \mathrm{~W}$

$117182 X$

$117182 Y$

1171822

1171830

1171831

1171832

1171833

1171834

1171835

1171836

1171837
Functional simulator for sensor-based embedded systems [11718-116]

Price-performance ratio analysis of advanced LED lighting applications [11718-117]

MPPT solar charge controller for automotive industry [11718-118]

Polymer dispersed liquid crystals doped with nanoparticles: electric and electro-optical properties (Invited Paper) [11718-121]

LED lighting system with gradual control of light intensity through capacitive sensing [11718-122]

Intelligent lighting system using single shot multibox detector [1 1718-123]

Polarized emission and dielectric studies of novel lanthanidomesogens based on 4-pyridone ligands [11718-125]

Properties of naval steel surface after non-thermal plasma treatment [11718-127]

Adsorption, wicking behavior and photodegradation tests of Rhodamine B solution upon wool substrates [11718-128]

Benefit of SqueeSAR filtering in topography reconstructions: an example over the Bucharest area with TerraSAR-X [11718-129]

TL-TensorFlow CNN model and dataset for electronic equipment [11718-130]

Description of underwater noise in Siutghiol lake, Constanta [11718-137]

Biological contamination of naval steel surface after non-thermal plasma treatment (Invited Paper) [11718-138]

Performance-oriented PIC10F N-core simulator [11718-139]

Power supplies for DBD used for surface treatments [11718-140]

Computer-based analytical model of a crankshaft throw strength problem [11718-141]

Software implementation strategies for telecommunications problems [11718-143]

Modelling and simulation of datalogging embedded module with solar panel supply and NiMH battery energy storage [11718-144]

Proposed pattern for data confidentiality in wireless communications [11718-146]

Procedures to keep the voice of "intelligent objects" alive [11718-147] 
$1171838 \quad$ Impact reduction of common mode currents for field measurements on directional symmetrical antennas [11718-148]

$1171839 \quad$ High reliability hybrid power supply systems for PON passive and AON active optical communications networks [11718-155]

Proc. of SPIE Vol. $117181171801-9$

Downloaded From: https://www.spiedigitallibrary.org/conference-proceedings-of-spie on 26 Apr 2023 Terms of Use: https://www.spiedigitallibrary.org/terms-of-use 
Proc. of SPIE Vol. 11718 1171801-10 Downloaded From: https://www.spiedigitallibrary.org/conference-proceedings-of-spie on 26 Apr 2023
Terms of Use: https://www.spiedigitallibrary.org/terms-of-use 